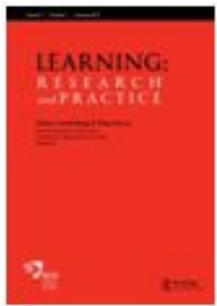

\title{
Which conditions facilitate the effectiveness of large-group learning activities? A systematic review of research in higher education.
}

\begin{tabular}{|c|l|}
\hline Journal: & Learning: Research and Practice \\
\hline Manuscript ID & RLRP-2020-0018.R1 \\
\hline Manuscript Type: & Regular Article \\
\hline Keywords: & $\begin{array}{l}\text { active learning, educational research, higher education, instructional } \\
\text { effectiveness, large group instruction }\end{array}$ \\
\hline & $\begin{array}{l}\text { Large-group activities has increased in higher education since year 2000. } \\
\text { Research focused on the possibility to have positive effects on students' } \\
\text { learning, regardless the number of students by identifying facilitating } \\
\text { factors. Hence, the achievement of learning results is used as a criterion } \\
\text { of effectiveness. This review summarizes the findings of research studies } \\
\text { on conditions that determine the effectiveness of large-group learning } \\
\text { activities in higher education contexts published from 1996 to 2016. The } \\
\text { PRISMA declaration for conducting literature reviews was followed. } \\
\text { Articles were searched through the ERIC, Web of Science, SCOPUS, } \\
\text { SCIELO, and EBSCO databases, including additional sources. A total of } \\
\text { seventy-eight articles met the inclusion criteria and were selected for a } \\
\text { thematic analysis. These studies came from a wide range of disciplines, } \\
\text { type of institutions and locations. Five themes emerged as conditions } \\
\text { that facilitate the effectiveness of large-group learning activities: (1) } \\
\text { student-teacher and student-student interaction, (2) implementation of } \\
\text { active learning strategies, (3) classroom management, (4) students' } \\
\text { motivation and commitment, (5) and the use of online teaching } \\
\text { resources. The discussion is centered on the conditions by which large- } \\
\text { group activities can be effective learning strategies in terms of student's } \\
\text { achievement of learning outcomes. }\end{array}$ \\
\hline Abstract \\
\hline
\end{tabular}

\section{SCHOLARONE" Manuscripts}




\section{Which conditions facilitate the effectiveness of large-group learning activities? A systematic review of research in higher education. \\ Which conditions facilitate the effectiveness of large-group learning activities? A systematic review of research in higher education.}

Large-group activities have increased in higher education since 2000. Research focused on the possibility to have positive effects on students' learning, regardless the number of students by identifying facilitating factors. Hence, the achievement of learning results is used as a criterion of effectiveness. This review summarizes the findings of research studies on conditions that determine the effectiveness of large-group learning activities in higher education contexts published from 1996 to 2016 . The PRISMA declaration for conducting literature reviews was followed. Articles were searched through the ERIC, Web of Science, SCOPUS, SCIELO, and EBSCO databases, including additional sources. A total of seventy-eight articles met the inclusion criteria and were selected for a thematic analysis. These studies came from a wide range of disciplines, type of institutions and locations. Five themes emerged as conditions that facilitate the effectiveness of large-group learning activities: (1) student-teacher and student-student interaction, (2) implementation of active learning strategies, (3) classroom management, (4) students' motivation and commitment, (5) and the use of online teaching resources. The discussion is centered on the conditions by which large-group activities can be effective learning strategies in terms of student's achievement of learning outcomes.

Keywords: active learning; educational research; higher education; instructional effectiveness; large group instruction; literature reviews. 


\section{What factors influence the effectiveness of large-group learning activities? A systematic review of research in higher education.}

\section{Introduction}

Numerous studies have focused on the effect of class size on the effectiveness of learning activities, reaching equivocal conclusions among themselves (Arias \& Walker 2004; Hejmadi 2007; Bedard \& Kuhn 2008; Kokkelenberg et al 2008, Johnson 2010; Cheng 2011; Ake-Little et al 2020). Some authors have questioned their effectiveness on students' learning outcomes and quality of education (Ehrenberg et al. 2001; Cuseo 2007; Diette \& Raghav 2015). The main arguments focus around the idea that with a larger class the educator has little opportunity to address the needs of individual students, thus focusing on the 'middle' of the cohort (Allais 2014). This leaves behind those students that are struggling and disengages those who may be considered advanced (Aravanitakis 2014). Others challenge teachers and researchers to reconsider this ubiquitous learning strategy, especially in the context of mass online classes (Nagel \& Kotzé 2010; Qiu et al 2012).

Also, there is no general consensus on what 'large-group' learning activities are. On the one hand, a number of authors have considered that between 300 and 1000 students (or more) are needed for a class to be considered 'large' (Foley \& Masingila, 2014; Prosser \& Trigwell, 2013). On the other hand, other authors postulate that it is not a specific number that defines if an activity is small or large, but whether the number itself presents real or perceived challenges (Maringe, \& Sing; 2014) or when the teacher is unable to make sustained eye contact with the students, in one room, for a standard period of 50 minutes. For this study, the above definition of large class was considered, that is, not based on a specific number of students, but rather from the perspective of teachers or researchers.

In the last decades, there has been a market increment in higher education, reflected in an enlarged number of young people with a tertiary degree in all OECD countries between 2009 and 2019 (OECD; 2020). For instance, 
domestic and international students in Australia have duplicated over the last 20 years (Norton 2013). The increase in students pursuing higher education mainly in Latin America, Australia, and Asia has not been proportional to the ratio of teachers per students, creating a need for massification of education (Lian 2013, Prosser and Trigwell 2013). Furthermore, higher enrolment rates have increased tensions between the development of competencies in small groups and the longterm financial sustainability of diverse institutions (Saiz 2014), primarily due to the cost of employment of qualified teaching staff. This new context presents the need to use economical and effective methods to convey information to large groups. Hence, the sudden irruption of technologies in higher education communities, such as MOOCs, online videos, mobile devices, and different related software, expand the possibilities of large-group activities (Nagel \& Kotzé 2010; Qiu et al 2012).

The importance of conducting varied and active learning activities (Brown, Manogue, 2001; Swanwick 2014) in the context of large classes relates to the conclusion that lectures are at least as effective as other teaching methods at presenting information and providing explanations (Spence, 1928; McLeish, 1976; Dunkin, 1983, 1986; Brown, 1987; Brown \& Atkins, 1988, 1997; Bligh, 2000). In relation to the above, some authors suggest that it is possible to provoke thought, deepen understanding and enhance scientific and critical thinking in large audiences without having to schedule multiple teaching sessions (Brown \& Manogue 2001) by engaging the "community of learners" to provide different perspectives on a subject and enhancing the possibilities to share knowledge amongst the participants involved (Long \& Lock, 2013). Thus, displaying an opportunity to settle the new information in relation to the student's previous knowledge. As it was described by Long and Lock (2013), "The resultant new knowledge will be unique to the learner as it is the result of selective attention an engaged interest, and the product of the learner's active efforts to relate new knowledge to pre-existing concepts" (p.140)

Most studies investigating large-group activities have focused on evidencing the achievement of students' learning outcomes; however, much less is known about what makes an effective large-group learning session. We 
assessed the literature to determine the key factors that facilitate the effectiveness of large-group learning activities and that are being used to result in improved outcomes for students.

\section{Methods}

A systematic review, following PRISMA statement for reporting systematic reviews and meta-analysis, was conducted. Systematic reviews have been previously used in other investigations to report results regarding the effect of class size on the effectiveness of learning (Rutter \& Maughan 2002 \& Carpenter 2006). However, it is important to note that such studies have not been carried out since 2006 .

\section{Data collection}

The review was conducted between December 2015 and January 2016, receiving approval from the University's ethics review committee, as being part of a larger project. To capture as many relevant citations as possible, a wide range of databases were searched to identify primary studies focusing on largegroup learning activities in higher education. More specifically, articles for this review were sourced from the following databases: ERIC, Web of Science, SCOPUS, SCIELO, and EBSCO. Furthermore, Google Scholar was included as an additional source as it has been referred to as a good resource that provides a broad range of literature across different fields of study, as well as for accounting for publication bias (Saadatdoost et al. 2015). There were restrictions placed on the language of publications, including studies either in English or Spanish, and year of publication, including articles published from 1996 to 2016 to provide an updated review.

Three essential concepts were identified for the search strategy: ("large group" OR "large class size") AND ("learning outcomes" OR "impact on learning") AND ("higher education" OR "University students"). Each essential concept was expanded considering synonyms, alternative spelling, and related terms. Nevertheless, each database has its own indexed subject headings; therefore, we adapted our keyword combination according to each thesaurus. 
All retrieved articles were exported to a reference manager for selection procedures. To be included in the review, all references were assessed based on the inclusion/exclusion criteria described in Table 1. The article selection process was based on the PRISMA statement for reporting systematic reviews and meta-analysis, shown in Figure 1, divided in four phases. Selecting a protocol for systematic reviews is important to increasing the transparency of the research process and reliability of published papers (Moher et al 2015). PRISMA was selected because some of the researchers had previous experience in other systematic reviews implementing that protocol (Jerez, Orsini \& Hasbun 2016).

Phase one corresponded to the identification of references from the aforementioned sources. Subsequently, in the screening phase, duplicates and irrelevant titles were removed. The abstracts of the remaining articles were reviewed using the inclusion/exclusion criteria. When there was doubt on the exclusion of a particular article, it was advanced to the eligibility phase, so it could be assessed based on the full text rather than on the abstract. In this phase, the full text of each article was screened, enabling a final decision. Subsequently, applying the same three phases, an ancestry search of the selected articles' references was conducted through the Web of Science. Finally, stage four was dedicated to assessing the selected articles' quality and alignment with the inclusion criteria. Phase two, three, and four were conducted by two authors independently (O.M.J \& C.A.O) and moderated by a third author whenever in disagreement.

As a mixture of qualitative and quantitative papers were expected to emerge, we opted for a semi-structured quality analysis instrument, the 'Questions to ask of research or evaluation evidence (Harden et al. 1999). This appraisal instrument is applicable to several methods; it has 17 items responding to a 'yes/no' question aimed at analysing the quality of different areas of a research paper. Articles that were assessed with two 'No' were automatically excluded, while articles with one 'No' were further analysed for inclusion. 


\section{Data Analysis}

As methodological heterogeneity was expected by the inclusion of qualitative and quantitative studies, the review was approached as a narrative synthesis through a thematic analysis using the ATLAS.ti ${ }^{\circ}$ software version 1.0.50. For the first step, the software was set up and all the extracted papers were imported. The unit of analysis was focused on the identification of factors that have been found to facilitate large-group learning activities. The thematic analysis is an appropriate qualitative method when working in research teams and analyzing large qualitative data sets (Nowell et al 2017). In this study, it facilitated the translation of concepts between studies by identifying prominent themes and summarizing their findings under recurrent headings, therefore allowing the integration of qualitative and quantitative evidence (Thomas and Harden 2008).

The thematic analysis was organised in three phases. The first phase was an open coding stage based on constant comparison and mainly aimed at reducing the data, extracting the essential ideas and resulting in the grouping of segments into different categories, i.e., factors that facilitate the effectiveness of large-group learning activities. The second phase was a central coding stage, aimed at combining and relating different categories amongst each other and grouping them into themes. Finally, the third phase was an interpretative stage aimed at drawing conclusions and reflecting on the findings. Two authors independently analysed the data, to finally reach an agreement on the final report.

\section{Results}

Electronic and additional sources identified 1,735 references. When duplicates and irrelevant titles were removed, 476 papers were forwarded for abstract screening and full-text assessment. Of these, 78 met the eligibility criteria and were rated as good quality evidence in order to be included in this study. Fig. 2 presents a flowchart summarising the selection process.

From an historical point of view, the studies report an increase in educational research focusing on large-group activities from 2000 onwards. At 
the same time, contrary positions and criticism towards this teaching strategy were found throughout the 20 years of reviewed research. Moreover, it is important to emphasise that this method was found to be transversal to a wide range of disciplines, types of institutions and locations.

The review identified 14 studies that postulated serious criticism and concerns on the effectiveness of large-group activities (Table 2), focusing mainly on the negative effects over students' performance. For instance, two studies analysed the outcomes of several large-group activities over a period of 8 or more years, concluding that as the number of students increase, learning outcomes decrease (Gibbs et al. 1996, Bedard \& Kuhn 2008). This is supported by several studies, which were conducted in shorter periods and included a smaller sample (Arias \& Walker 2004, Cuseo 2007, Kokkelenberg et al. 2008, Johnson 2010, Persky \& Pollack 2010, Cheng 2011a, Kooloos et al. 2011, Truelove et al. 2013). In the same vein, Allais (2014) considers that large-group activities not only lead to poor results, but they also thwart the direct contact that can be established amongst students and teachers, which is a crucial element towards the development of disciplinary knowledge. That said, it is important to stress that most of the aforementioned studies reached their conclusions by establishing correlations or cause-effect between the number of students and their academic performance, as well as by the students' and teachers' perception, not considering methodological factors.

On the other hand, Persky \& Pollack (2010), Kooloos et al. (2011) and Truelove et al. (2013), took into account the teaching strategy, number of students, and their academic performance, and concluded that there were no significant differences between large or small groups if certain conditions were met. An example of this is the implementation of interteaching strategies like pair discussion after a lecture. This contributes to diminishing social dallying because of the identifiable participation of each one of the students. Beyond the criticism towards large-group activities, the majority of the reviewed studies postulate that the overcrowding of classrooms represents an opportunity for educational researchers to recommend creative solutions to encourage learning. An example of these, would be the combination of face to face teaching with online activities to offer a blended learning approach, using technology as a tool to cope with large group activities drawbacks (Hornsby and Osman 2014). 
The remaining 64 studies reported and concluded that it is possible to obtain positive effects on students and on their learning in large-group activities.

The review identified 5 common factors that facilitate their effectiveness and should be taken into consideration when implementing large-group activities (Table 2).

\section{Factor 1 - Interactions}

The first identified factor is related to the student-student and studentteacher interactions (Yang et al. 2007, Nelson et al. 2009), and to students' cognitive participation (Jin and Shin 2012).

The relevant role of teacher-student relationships has been mentioned many times, but rarely reported (Pennung and Hollentesin 2020). Furthermore, positive teacher-student relationships are associated with improvements of learning outcomes in both a cognitive and motivational level (Cornelius-White, 2007; Den Brok, Brekelmans, and Wubbels, 2004; Roorda, Koomen, Spilled, and Oort, 2011) and of the teachers themselves Spilt, Koomen, \& Thijs, 2011).Considering the fact that face to face direct interaction is complicated in massive classrooms, the use of Student Response Systems (SRS), known as "clickers", has emerged as a learning activity that by means of improving the overall interactions within the participants of the class, proved to encourage participation and willingness to learn (Denker 2013). In addition, teacher feedback was demonstrated to have a positive effect on student's cognitive engagement (Arvanitakis 2014). Furthermore, pedagogical approaches originated from social constructivism such as Problem-based learning, ProjectOriented Guided Inquiry Learning, and hybrid methods that combine these strategies with the traditional lectures proved to be useful in improving learning outcomes through allowing opportunities for social engagement and interactions in large group of students (Swap \& Walter 2015). Consequently, these interactions should be proposed as creative and sustainable instances (Clarence et al. 2013), in order to promote students' motivation, engagement, learning efficiency, and encourages students' involvement in their learning process (Denker 2013, Arvanitakis 2014). 


\section{Factor 2 - Active Teaching and learning methods}

Active teaching and learning methods can be defined as strategies that promote the participation of students in a way that encourages them to perform tasks and activities towards their learning process, instead of the traditional passive experience. Active methods of teaching and assessment enhance cognitive participation and should be used in order to positively impact students' learning outcomes (Schmitt-Harsh and Harsh 2012, Wixon \& Balser 2012, Johanson et al. 2013, Lian 2013, Miller et al. 2013). This factor was the most recurrent amongst the revised studies, emphasising the fact that the most commonly used methods that make a positive impact on students' learning are peer assisted learning (Cooper and Robinson 2000a, Hejmadi 2007, StangerHall et al. 2010) where students with a greater mastery of certain learning, facilitate group or individual activities in formal and informal group learning (Alcaide, 2015; Cooper \& Robinson, 2000; Exeter et al., 2010; Lin, Huang, \& Cheng, 2010; Nicholl \& Lou, 2012). Examples are study groups in social networks, where students manage to support themselves in real time when facing certain challenges, alongside the assessment, evaluation and feedback between blind peers (Nagel and Kotzé 2010, Johanson et al. 2013) since when students review their peers' work in a systematic way, it favors the learning process (Jerez et al, 2017). It is also emphasised that the implementation of large-group activities should be planned encouraging students' involvement, empowering them and fostering their autonomy, regardless of the number of students in-class (Lewis and Lewis 2008, Prosser and Trigwell 2013, Calzada et al. 2014, Alcaide 2015).

\section{Factor 3 - Classroom Management}

Classroom management arose as the third identified factor, as it stands for a change in the current management and administration of the in-class learning process. Hence, there is a need to coordinate different actions, which involves the design and organisation of teaching and learning activities (Cooper \& Robinson, 2000), and the way they are assembled and coordinated with the teaching team when large-group activities are implemented (Klegeris et al., 2013; Lin et al., 2010; Nelson et al., 2009). Moreover, it implies the integration of permanent methodological facilitators (Ochsendorf et al. 2006, Nicholl and Lou 
2012), as well as coordination handouts, technological material, and the assessment of coursework, amongst others (Renaud et al., 2007). In addition, Renaud emphasises the importance of setting classroom rules and planning a variety of activities in order to maintain discipline among the students (Renaud 2007).

Several articles described the use of different strategies that generated an organizational change in classrooms. The incorporation of virtual resources and organizing students in smaller groups for discussion facilitated the administration of the class and enhanced the interactions among the students. (Calzada et al., 2014). Another example is Problem Based Learning ( $P B L)$ which proved to improve learning outcomes not only by boosting social engagement, but also throughout a shift in the traditional organization of a lecture course. Klegeris (2013), described a successful Tutor-less PBL strategy using generic problemsolving tests to assess improvement in problem solving abilities. The successful results of these experiences emerge as proof that even when money and time resources are limited, learning outcomes can be accomplished throughout the application of classroom management strategies.

For example PBL related to contingency favors learning, especially when the dynamic is centered in the search for solutions that are relevant to the students' own lives, such as natural or socioeconomic disasters that their communities might be facing.

\section{Factor 4- Students motivation and engagement}

The fourth factor was related to students' motivation and engagement. The type of motivation that a student has in class is related to effective and cognitive educational outcomes, directly influencing engagement and mobilization of learning. Cahill (2014) showed that by means of an interactive engagement curriculum, attitudinal benefits are produced relative to what students personally experience among traditional lecture courses, implying that with the appropriate teaching strategies, large classes can "feel smaller" and motivate students towards better learning outcomes (Goodman 2005). Renaud, states that the level and type of motivation in a heterogeneous class is essential for maintaining a proper learning environment, as boredom and lack of interest 
directly affect classroom management and the effective application of active learning strategies (Renaud 2007). In consequence, there is a need to align the course expectations with the students' motives. The latter becomes a relevant element to consider when managing large-group activities (Renaud et al., 2007). As such, a large-group compared to a small one, should not necessarily show differences in students' learning outcomes, as long as all students are motivated and engaged in the learning process (Goodman et al. 2005). The latter is possible if relevant cognitive interactions within the activities are promoted by the teaching staff (Cahill et al., 2014; Tomkinson \& Hutt, 2012), which have the potential to support and enhance motivation (Denker, 2013; Exeter et al., 2010; Hejmadi, 2007).

\section{Factor 5- Use of online teaching resources}

The use of online teaching resources was considered as important aids that help solving the challenges of large-group activities, through the involvement of other learners and the readily available electronic resources inside and outside the classroom (Doucet et al. 2009, Halic et al. 2010, Elavsky et al. 2011, Saunders and Gale 2012, Brady et al. 2013, Foley and Masingila 2014). Online teaching resources allow teachers to:

- Improve lectures (Dollman 2005),

- Create and use in class electronic tools that facilitate real-time interactions such us : Kahoot, Mentimeter, and Socrative.

- Engage with teachers, professionals or students from other countries through videoconferences.

- Generate out-of-class learning spaces (Bryant 2005, Azzawi and Dawson 2007, Qiu et al. 2012, Kim 2013, Bati et al. 2014, Shaw et al. 2015),

- Design blended learning courses (Bati et al. 2014, Snowball 2014).

The benefits of these possibilities have been classified by Salmon (2002) in 4 categories: 1) provide active educational experiences for all students enhancing the participation of the class, 2) an opportunity towards self-paced learning, 3) access to resources without any time or geographical limitations, 4) increase interaction among students through sub-grouping and collaborative learning. 


\section{Discussion}

This review established 5 common factors that ease the effectiveness of large group activities. These factors can all be framed from a constructivist pedagogical perspective, since they tend to focus on students, the learning process, and the constructions of knowledge for themselves. However, these could apparently be in opposition to higher education practices, considering the different disciplinary spaces and curricular knowledge as the only valid references (O'Connor, K., 2020). However, in a constructivist approach, the identified factors establish a bridge between the hard sciences, the human sciences and the historical disciplines; that is to say, a systemic vision on learning (Peterson, 2012).

The first proposed factor relates to interactions within the group of students and their teachers. It has been described that face-to-face contact interaction seems to be essential to the development of knowledge (Allais, S., 2014.), as real time meetings are the situations from which intellectual activities historically arise (Collins, 1998). The reason could be explained from a sociological standpoint, as it has been widely described that individuals act different in groups than how they act by themselves. An example of this are interaction rituals described in societies, in which an individual 's sense of identity, solidarity and energy promote actions that an individual would not do on their own (Collins, 2004). However, the intrinsic nature of human relations has turned towards instant connection improving time and place management. Multitasking has played an essential role in the development of new generations, creating a need for educators to understand these changes in order to improve affinity with their students. On the other hand, taken into account students' diversity, cultural and socioeconomic differences, and singular learning skills would be likely to strengthen students' disposition towards the learning process.

Proceeding to the most frequent factor described in the reviewed studies, which was the implementation of teaching strategies that promote active participation of students, this investigation group postulates that the belief that the ideal group of students should be small in order to allow active participation of all students involved constitutes a denial of the local reality and an idealization of the educational process. In this sense, online teaching resources, which is the 
fifth identified factor, should be used and included in an educational strategy because it embraces each student in their individuality, enabling active participation of the entire class. In the same vein, the massification of new technologies should be understood as a tool to promote personalization of the learning process, favouring the involvement of each and every student in their particularities. On the other hand, classroom management which arose as the third essential element to consider in a successful large group activity is also intrinsically connected to the use of online teaching resources as they allow monitorization of the students during the development of the lesson providing essential feedback that improves learning outcomes. An example of these new technologies is software like Kahoot $₫$ and Socrative $®$. Moreover, it opens possibilities towards the creation of learning spaces not only before the class, but also during and after the class. In consequence a positive or negative outcome cannot be entirely attributed to the number of students, but to the strategies that teachers use to cope with this difficulty.

Finally, students' motivation and engagement were the fourth component to consider. Autonomous motivation is defined as commitment out of pleasure and satisfaction and/or by valuing the relevance of certain activity. In this sense it has been related with positive educational outcomes. Teachers should take this into consideration when designing learning strategies because of the effect interpersonal experiences have in a student's level and type of motivation. (Orsini, Binnie, Wilson, 2016).

\section{Conclusions}

Given the fact that an increasing number of students are pursuing higher education, large-group classes are a reality for many Higher Education Institutions and have placed teachers at crossroads: which factors should be considered when implementing large-group activities? How large-group activities can be effectively used to support learning in large class settings?

Although many authors have focused on criticising large classes instead of finding creative and innovative solutions for it (Gibbs et al. 1996, Arias and Walker 2004, Cuseo 2007, Kokkelenberg et al. 2008, Bedard and Kuhn 2008, Cardozo et al. 2008, Persky and Pollack 2010, Johnson 2010, Kooloos et al. 
2011, Cheng 2011a, 2011b, Truelove et al. 2013, Westphalen 2013, Allais 2014, Saiz 2014, Hornsby and Osman 2014), this review has identified 5 factors that when taken into consideration are likely to improve the learning outcomes of large group activities.

The outburst of new technologies opens possibilities towards innovation in educational contexts. Smartphones amongst other mobile devices have made it possible to access resources in a variety of contexts and situations, students can learn at any time and place, "ubiquitous learning" (Wang, Zhang, Yang, 2017) which is the opportunity to use resources not only intentionally, but also circumstantially is becoming a reality. Therefore, the role of books in the past is being replaced by mobile devices, allowing not only a variety of teaching methods that are more likely to fit each student's personal learning abilities, but also improving time administration, enduring personalization of the learning process. As an example of time management improvement, it would be interesting to evaluate the effect of mobile software designed to allow higher education students review their lectures during commuting time on public transportation, which would allow them to take profit of these otherwise "dead times". In this sense, future research should focus on how mobile devices, such as smartphones and tablets, can become (or not) powerful allies, and on which type of apps are required for the development of specific and generic competences.

Exploring the real impact of large-group activities has been a difficult task as a larger group of students implicates more variables influencing the effectiveness of teaching methods (Franklin \& Theall 1995, Goodman et al. 2005, Cuseo 2007). A deep understanding of the teaching and learning process and the elements that affect it constitutes an opportunity and a challenge towards creativity to improve the effectiveness of the educational process, assuring its quality (Arvanitakis 2014),

One of the limitations of the present study is related to the operationalization of the term "large group learning". In this sense, when incorporating "large class size" as one of the searched concepts in the systematic review, it implies that each investigation operationalizes size in a different way. 
Other investigations could delve into the classification of studies based on their conception of large groups. Likewise, it could be interesting to carry out an analysis of the methodology used on the field, that could identify gaps for future research regarding class size and its effect on the effectiveness of learning activities. 


\section{References}

Ake-Little, E., von der Embse, N., \& Dawson, D. (2020). Does Class Size Matter in the University Setting? Educational Researcher, 0013189X20933836.

Alcaide, X. M. (2015). Métodos de Diálogo con Grandes Grupos. Herramientas para afrontar la complejidad. Large Group Methods: Tools for Dealing with Complexity., (51), 186-197.

Allais, S., (2014) A critical perspective on large class teaching: The political economy of massification and the sociology of knowledge. Higher Education, 67 (6), 721-734.

Arias, J.J. and Walker, D.M., (2004) Additional Evidence on the Relationship between Class Size and Student Performance. Journal of Economic Education, 35 (4), 311-329.

Arvanitakis, J., (2014) Massification and the large lecture theatre: From panic to excitement. Higher Education, 67 (6), 735-745.

Azzawi, M., \& Dawson, M. (2007). The Effectiveness of Lecture-Integrated, WebSupported Case Studies in Large Group Teaching. Bioscience Education, 10(1), 1-12.

Bati, T.B., Gelderblom, H., and van Biljon, J., (2014) A blended learning approach for teaching computer programming: design for large classes in SubSaharan Africa. Computer Science Education, 24 (1), 71-99.

Bedard, K. and Kuhn, P., (2008) Where class size really matters: Class size and student ratings of instructor effectiveness. Economics of Education Review, 27 (3), 253-265.

Bligh, D.A., (2000) What's the Use of Lectures? (San Francisco, Jossey-Bass).

Bonwell, C.C. and Eison, J.A. 1991. Active learning: creating excitement in the classroom. Higher Education Report No. 1 George Washington University.

Brady, M., Seli, H., and Rosenthal, J., (2013) 'Clickers' and metacognition: A quasi-experimental comparative study about metacognitive self-regulation and use of electronic feedback devices. Computers and Education, 65, 5663.

Brown, G.A., (1987) Studies of lecturing, in: M.J. DUNKIN (Ed) International Encyclodaedia of Teacher Education (Oxford, Pergamon).

Brown, G.A. and Atkins, M.J., 1988. Effective Teaching in Higher Education (London, Methuen). 
Brown, G., \& Manogue, M. (2001) AMEE Medical Education Guide No. 22: Refreshing lecturing: a guide for lecturers. Medical Teacher, 23(3), 231-244. Bryant, B.K., (2005) Electronic Discussion Sections: A Useful Tool in Teaching Large University Classes. Teaching of Psychology, 32 (4), 271-275.

Cahill, M., Hynes, K., Trousil, R., Brooks, L., McDaniel, M., \& Repice, M. et al. (2014) Multiyear, multi-instructor evaluation of a large-class interactiveengagement curriculum. Physical Review Special Topics - Physics Education Research, 10(2).

Calzada, V., Lecot, N., Fernanda García, M., Cabrera, M., Camacho, X., Tassano, M., Castelli, R., Czerwonogora, A., Goicochea, E., González, M., Cabral, P., and Cerecetto, H., (2014) Cursos masivos: ampliando expectativas. Educación Química, 25, Supple, 254-257.

Cardozo, S.M.I., Andino, G.M., Beatriz, A., Esquivel, B., and Espindola, E., (2008) Efectividad de los métodos activos como estrategia de enseñanzaaprendizaje en grupos grandes y heterogeneous. Effectiveness of the active methods as a teaching-learning strategy in large and heterogeneous groups., 22 (1), 1-6.

Carpenter, J. M. (2006). Effective teaching methods for large classes. Journal of Family \& Consumer Sciences Education, 24(2).

Cheng, D.A., (2011) Effects of Class Size on Course and Professor Evaluations Across Disciplines. SSRN Electronic Journal, 30 (5), 980-990.

Clarence, S., Albertus, L., and Mwambene, L., (2013) Building an evolving method and materials for teaching legal writing in large classes. Higher Education, 67 (6), 839-851.

Collins, R. (1998) The Sociology of philosophies. A global theory of intellectual change. Cambridge, MA: The Belknap Press of Harvard University Press (25).

Collins, R. (2004) Interaction ritual chains. Princeton and Oxford: Princeton University press (34)

Cooper, J.L. and Robinson, P., (2000a) The Argument for Making Large Classes Seem Small. New Directions for Teaching and Learning, 2000 (81), 5-16.

Cooper, J.L. and Robinson, P., (2000b) Getting Started: Informal Small-Group Strategies in Large Classes. New Directions for Teaching and Learning, 2000 (81), 17-24. 
Cuseo, J., (2007) The empirical case against large class size: Adverse effects on the teaching, learning, and retention of first-year students. Journal of Faculty Development, 21 (1), 5-21.

Diette, T., \& Raghav, M. (2015). Class size matters: Heterogeneous effects of larger classes on college student learning. Eastern Economic Journal, 41(2), 273-283. http://dx.doi.org/10.1057/eej.2014.31

Denker, K.J., (2013) Student Response Systems and Facilitating the Large Lecture Basic Communication Course: Assessing Engagement and Learning. Communication Teacher, 27 (1), 50.

Dollman, J., (2005) A new peer instruction method for teaching practical skills in the health sciences: An evaluation of the 'Learning Trail'. Advances in Health Sciences Education, 10 (2), 125-132.

Doucet, M., Vrins, A., and Harvey, D., (2009) Effect of using an audience response system on learning environment, motivation and long-term retention, during case-discussions in a large group of undergraduate veterinary clinical pharmacology students. Medical Teacher, 31 (12), e570_ e579.

Dunkin, M.J., (1983) 'A review of research on lecturing', Higher Education Research and Development 2, pp. 63-78.

Elavsky, C.M., Mislan, C., and Elavsky, S., (2011) When talking less is more: exploring outcomes of Twitterusage in the large-lecture hall. Learning, Media and Technology, 36 (3), 215-233.

Exeter, D.J., Ameratunga, S., Ratima, M., Morton, S., Dickson, M., Hsu, D., and Jackson, R., (2010) Student engagement in very large classes: the teachers' perspective. Studies in Higher Education, 35 (7), 761-775.

Foley, A.R. and Masingila, J.O., (2014) Building capacity: challenges and opportunities in large class pedagogy (LCP) in Sub-Saharan Africa. Higher Education, 67 (6), 797-808.

Franklin, J. and Theall, M., (1995) The relationship of disciplinary differences and the value of class preparation time to student ratings of teaching. New directions for teaching and learning, 1995 (64), 41-48.

Gedalof, A., (1999) Green Guide No. 1 Teaching Large Classes. London, Ontario: Society for Teaching and Learning in Higher Education. 
Gibbs, G., Lucas, L., and Simonite, V., (1996) Class size and student performance: 1984-94. Studies in Higher Education, 21 (3), 261-273.

Goodman, B.E., Koster, K.L., and Redinius, P.L., (2005) Comparing biology majors from large lecture classes with TA-facilitated laboratories to those from small lecture classes with faculty-facilitated laboratories. Advances in Physiology Education, 29 (2), 112-117.

Grauer, G.F., Forrester, S.D., Shuman, C., and Sanderson, M.W., (2008) Comparison of student performance after lecture-based and casebased/problem-based teaching in a large group. Journal of veterinary medical education, 35 (2), 310-317.

Halic, O., Lee, D., Paulus, T., and Spence, M., (2010) To blog or not to blog: Student perceptions of blog effectiveness for learning in a college-level course. The Internet and Higher Education, 13 (4), 206-213.

Harden, R., Grant, J., Buckley, G., and Hart, R., (1999) BEME Guide No. 1: Best Evidence Medical Education. Medical teacher, 21 (6), 553-562.

Hejmadi, M. V, (2007) Improving the Effectiveness and Efficiency of Teaching Large Classes: Development and Evaluation of a Novel e-Resource in Cancer Biology. Bioscience Education, 9 (June).

Hornsby, D.J. and Osman, R., (2014) Massification in higher education: Large classes and student learning. Higher Education, 67 (6), 711-719.

Jerez, O., Baloian, N., \& Zurita, G. (2017, July). Authentic Assessment Between Peers in Online Courses with a Large Number of Students. In 2017 IEEE 17th International Conference on Advanced Learning Technologies (ICALT) (pp. 235-237). IEEE

Jerez Yáñez, Óscar, Orsini Sánchez, César, \& Hasbún Held, Beatriz. (2016). Atributos de una docencia de calidad en la educación superior: una revisión sistemática. Estudios pedagógicos (Valdivia), 42(3), 483506. https://dx.doi.org/10.4067/S0718-07052016000400026

Jin, S.-H. and Shin, S., (2012) The Effect of Teacher Feedback to Students' Question-asking in Large-sized Engineering Classes: A Perspective of Instructional Effectiveness and Efficiency. Asia-Pacific Education Researcher, 21 (January), 497-506. 
Johanson, K.E., Watt, T.J., Mclntyre, N.R., and Thompson, M., (2013) Purification and characterization of enzymes from yeast: an extended undergraduate laboratory sequence for large classes. Biochemistry and molecular biology education: a bimonthly publication of the International Union of Biochemistry and Molecular Biology, 41 (4), 251-261.

Johnson, I.Y., (2010) Class Size and Student Performance at a Public Research University: A Cross-Classified Model. Research in Higher Education, 51 (8), 701-723.

Kelly, D., Baxter, J.S., and Anderson, a., (2010) Engaging first-year students through online collaborative assessments. Journal of Computer Assisted Learning, 26 (6), 535-548.

Kim, J., (2013) Influence of group size on students' participation in online discussion forums. Computers $\{\&\}$ Education, 62, 123-129.

Klegeris, A., Bahniwal, M., and Hurren, H., (2013) Improvement in generic problem-solving abilities of students by use of tutor-less problem-based learning in a large classroom setting. CBE Life Sciences Education, 12 (1), 73-79.

Klegeris, A. and Hurren, H., (2011) Impact of problem-based learning in a large classroom setting: student perception and problem-solving skills. Advances in Physiology Education, 35 (4), 408-415.

Kokkelenberg, E.C., Dillon, M., and Christy, S.M., (2008) The effects of class size on student grades at a public university. Economics of Education Review, 27 (2), 221-233.

Kooloos, J.G.M., Klaassen, T., Vereijken, M., Van Kuppeveld, S., Bolhuis, S., and Vorstenbosch, M., (2011) Collaborative group work: Effects of group size and assignment structure on learning gain, student satisfaction and perceived participation. Medical Teacher, 33 (12), 983-988.

Lewis, S.E. and Lewis, J.E., (2008) Seeking effectiveness and equity in a large college chemistry course: an HLM investigation of Peer-Led Guided Inquiry. Journal of Research in Science Teaching, 45 (7), 794-811.

Lian, J., (2013) Improved Performance of Students Instructed in a Hybrid PBL Format. Biochemistry and Molecular Biology Education, 41 (1), 5-10.

Lin, Y.-T., Huang, Y.-M., and Cheng, S.-C., (2010) An automatic group composition system for composing collaborative learning groups using 
enhanced particle swarm optimization. Computers \{\&\} Education, 55 (4), 1483-1493.

Long, A. and Lock, B. (2013) Lectures and large groups, in Understanding Medical Education: Evidence, Theory and Practice (ed T. Swanwick), John Wiley \& Sons, Ltd, Chichester, UK.

MacGregor, J., (2000) Restructuring Large Classes to Create Communities of Learners. New Directions for Teaching and Learning, 2000 (81), 47-61.

Maringe, F., \& Sing, N. (2014). Theorising research with vulnerable people in higher education: Ethical and methodological challenges. South African Journal of Higher Education, 28(2), 533-549.

McLeish, J., (1976) The Lecture Method. In N.L. GAGE (ed) The Psychology of Teaching Methods 75th Yearbook of the National Society for the Study of Education, (Chicago, University of Chicago Press).

Milesi, C. and Gamoran, A., (2006) Effects of Class Size and Instruction on Kindergarten Achievement. Educational Evaluation and Policy Analysis, 28 (4), 287-313.

Miller, C.J., McNear, J., and Metz, M.J., (2013) A comparison of traditional and engaging lecture methods in a large, professional-level course. Advances in physiology education, 37 (4), 347-355.

Moher, D., Shamseer, L., Clarke, M. et al. Preferred reporting items for systematic review and meta-analysis protocols (PRISMA-P) 2015 statement. Syst Rev 4, 1 (2015). https://doi.org/10.1186/2046-4053-4-1

Mulryan-Kyne, C., (2010) Teaching large classes at college and university level: Challenges and opportunities. Teaching in Higher Education, 15 (2), 175185.

Nagel, L. and Kotzé, T.G., (2010) Supersizing e-learning: What a Col survey reveals about teaching presence in a large online class. The Internet and Higher Education, 13 (1-2), 45-51.

Naude, M. and Derera, E., (2014) Using the Case Study Method to Enhance the Learning Skills of Supply Chain Management Students, 28 (5), 351-359.

Nelson, J., Robison, D.F., Bell, J.D., and Bradshaw, W.S., (2009) Cloning the Professor, an Alternative to Ineffective Teaching in a Large Course. Education, 8 (3), 252-263. 
Nicholl, T. and Lou, K., (2012) A model for small-group problem-based learning in a large class facilitated by one instructor. American journal of pharmaceutical education, 76 (6), Article 117.

Nowell, L. S., Norris, J. M., White, D. E., \& Moules, N. J. (2017). Thematic Analysis: Striving to Meet the Trustworthiness Criteria. International Journal of Qualitative Methods. https://doi.org/10.1177/1609406917733847

O'Connor, K. (n.d.). Constructivism, curriculum and the knowledge question: tensions and challenges for higher education. STUDIES IN HIGHER EDUCATION. https://doi.org/10.1080/03075079.2020.1750585

OECD (2020), Education at a Glance 2020: OECD Indicators, OECD Publishing, Paris, https://doi.org/10.1787/69096873-en.

O'Reilly, N.J., Rahinel, R., Foster, M.K., and Patterson, M., (2007) Connecting in Megaclasses: The Netnographic Advantage. Journal of Marketing Education, 29 (1), 69-84.

Orsini, C., Binnie, V. I., \& Wilson, S. L. (2016) Determinants and outcomes of motivation in health professions education: a systematic review based on self-determination theory. Journal of Educational Evaluation for Health Professions, 13, 19.

Ochsendorf, F.R., Boehncke, W.-H., Sommerlad, M., and Kaufmann, R., (2006) Interactive large-group teaching in a dermatology course. Medical teacher, 28 (8), 697-701.

Persky, A.M. and Pollack, G.M., (2010) Transforming a large-class lecture course to a smaller-group interactive course. American journal of pharmaceutical education, 74 (9), 170.

Prosser, M. and Trigwell, K., (2013) Qualitative variation in approaches to university teaching and learning in large first-year classes. Higher Education, 67 (6), 783-795.

Qiu, M., Hewitt, J., and Brett, C., (2012) Online class size, note reading, note writing and collaborative discourse. International Journal of ComputerSupported Collaborative Learning, 7 (3), 423-442.

Qiu, M. and McDougall, D., (2015) Influence of group configuration on online discourse reading. Computers $\{\&\}$ Education, 87, 151-165. 
Renaud, S., Tannenbaum, E., and Stantial, P., (2007) Student-Centered Teaching in Large Classes with Limited Resources. English Teaching Forum, 3 (3), 12-18.

Rutter, M., \& Maughan, B. (2002). School effectiveness findings 19792002. Journal of school psychology, 40(6), 451-475.

Roberts, C., Lawson, M., Newble, D., Self, A., and Chan, P., (2005) The introduction of large class problem-based learning into an undergraduate medical curriculum: an evaluation. Medical teacher, 27 (6), 527-533.

Rohr, L.E. and Costello, J., (2015) Student Perceptions of Twitters' Effectiveness for Assessment in a Large Enrollment Online Course. Online Learning Journal, 19 (4).

Saadatdoost, R., Sim, A.T.H., Jafarkarimi, H., and Mei Hee, J., (2015) Exploring MOOC from education and Information Systems perspectives: a short literature review. Educational Review, 67 (4), 505-518.

Saiz, M., (2014) Economies of Scale and Large Classes. THOUGHT $\{\&\}$ ACTION, 149.

Salmon, G., (2002) E-tivities: The key to active online learning London, UK. Kogan Page

Saunders, F.C. and Gale, A.W., (2012) Digital or didactic: Using learning technology to confront the challenge of large cohort teaching. British Journal of Educational Technology, 43 (6), 847-858.

Schmitt-Harsh, M. and Harsh, J. a., (2012) The development and implementation of an inquiry-based poster project on sustainability in a large non-majors environmental science course. Journal of Environmental Studies and Sciences, 3 (1), 56-64.

Shaw, J., Kominko, S., and Lennox Terrion, J., (2015) Using LectureTools to enhance student-instructor relations and student engagement in the large class. Research in Learning Technology, 23.

Smith, K.A., (2000) Going Deeper: Formal Small-Group Learning in Large Classes. New Directions for Teaching and Learning, (81), 25-46.

Snowball, J.D., (2014) Using interactive content and online activities to accommodate diversity in a large first year class. Higher Education, 67 (6), 823-838. 
Spence, R.B., (1928) 'Lecture and class discussion in teaching educational psychology', Journal of Educational Psychology, 19 pp. 454-62

Stanger-Hall, K.F., Lang, S., and Maas, M., (2010) Facilitating learning in large lecture classes: Testing the 'teaching team' approach to peer learning. CBE Life Sciences Education, 9 (4), 489-503.

Swap, R.J. and Walter, J.A., (2015) An approach to engaging students in a largeenrollment, introductory STEM college course, 15 (5), 1-21.

Thomas, J. and Harden, A., (2008) Methods for the thematic synthesis of qualitative research in systematic reviews. BMC medical research methodology, 8 (1), 45.

Tomkinson, B. and Hutt, I., (2012) Online PBL: a route to sustainability education? Campus-Wide Information Systems, 29 (4), 291-303.

Truelove, J.C., Saville, B.K., and Van Patten, R., (2013) Interteaching: Discussion Group Size and Course Performance, 13 (2), 23-30.

Westphalen, L., (2013) Teaching Large Classes: The Magnificent Seven! The University of Adelaide, 1-9.

Wixon, D.L. and Balser, T.C., (2012) Environmental education for the masses: lessons from a large, general nrolment environmental studies course. Journal of Environmental Studies and Sciences, 2 (3), 239-248.

Woollacott, L., Booth, S., and Cameron, A., (2014) Knowing your students in large diverse classes: A phenomenographic case study. Higher Education, 67 (6), 747-760.

Wu, J., (2013) Mutation-Based Learning to Improve Student Autonomy and Scientific Inquiry Skills in a Large Genetics Laboratory Course. Cbe-Life Sciences Education, 12 (3), 460-470.

Wang, X. (2017). Construction of Course Ubiquitous Learning Based on Network. EURASIA Journal Of Mathematics, Science And Technology Education, 13. Yang, F., Wang, M., Shen, R., and Han, P., (2007) Community-organizing agent: An artificial intelligent system for building learning communities among large numbers of learners. Computers and Education, 49 (2), 131-147.

Yang, Y.-T.C., (2008) A Catalyst for Teaching Critical Thinking in a Large University Class in Taiwan: Asynchronous Online Discussions with the Facilitation of Teaching Assistants. Educational Technology Research and Development, 56 (3), 241-264. 
Figure 1. Flow chart summarising the review process with number of articles reviewed and retained at each stage. Adapted from PRISMA statement (Moher et al. 2009)

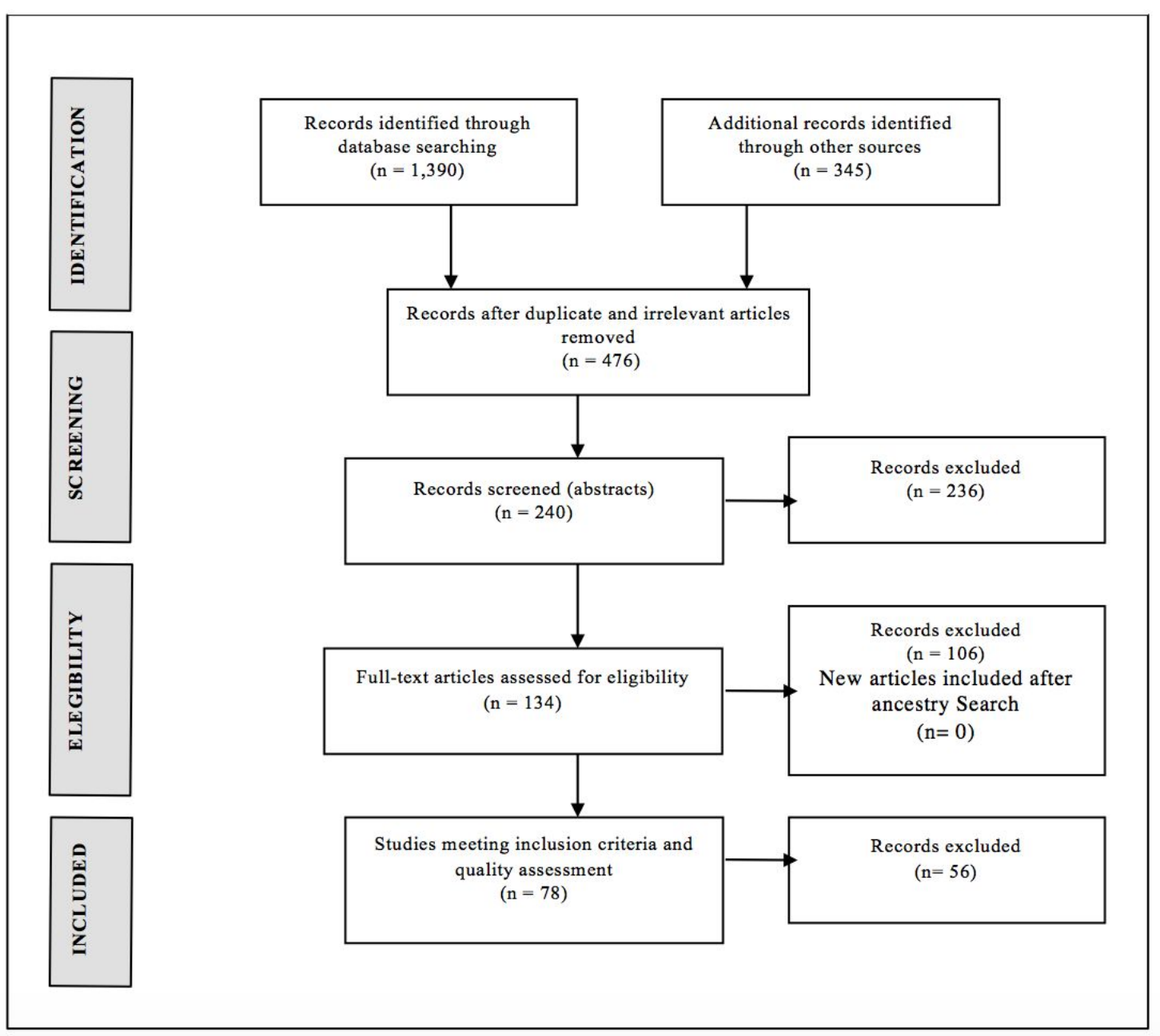


Table 1. Setting the scope of the search: inclusion and exclusion criteria.

Inclusion Criteria $\quad$ Exclusion Criteria

Empirical studies focusing on factors that determine the effectiveness of large-group learning activities.

Studies not empirical in nature like viewpoints, editorials, opinions or books.

Empirical studies that report research on students or teachers in higher education, at the undergraduate or postgraduate level.

Valid and reliable quantitative research.

Studies not focusing on large-group learning activities.

Credible and dependable qualitative Studies referring to large-group activities research. without a focus on higher education.

Articles published in English or Spanish

Studies published in languages other than English or Spanish.

Studies published from 1996 to 2016 . S Studies published before the year 1996. 
Table 2. Factors identified that facilitate the effectiveness of large-group learning activities and their source

\begin{tabular}{|c|c|c|}
\hline Factors & Key Findings & Sources \\
\hline 1. Interaction & $\begin{array}{l}\text { Student-student and } \\
\text { student-teacher } \\
\text { interactions and to } \\
\text { students' cognitive } \\
\text { participation engage } \\
\text { students in their learning } \\
\text { process affecting } \\
\text { learning outcomes } \\
\text { positively. }\end{array}$ & $\begin{array}{l}\text { Smith 2000, Milesi and } \\
\text { Gamoran 2006, Ochsendorf et } \\
\text { al. 2006, Yang et al. 2007, } \\
\text { Nelson et al. 2009, Stanger- } \\
\text { Hall et al. 2010, Lin et al. 2010, } \\
\text { Schmitt-Harsh and Harsh } \\
\text { 2012, Jin and Shin 2012, } \\
\text { Prosser and Trigwell 2013, Wu } \\
\text { 2013, Clarence et al. 2013, } \\
\text { Denker 2013, Lian 2013, } \\
\text { Arvanitakis 2014, Alcaide } \\
\text { 2015, Swap and Walter 2015 }\end{array}$ \\
\hline $\begin{array}{l}\text { 2.Active } \\
\text { teaching and } \\
\text { learning } \\
\text { methods }\end{array}$ & $\begin{array}{l}\text { Active methods of } \\
\text { teaching and } \\
\text { assessment enhance } \\
\text { cognitive participation of } \\
\text { students and positively } \\
\text { impact students' learning } \\
\text { outcomes, regardless } \\
\text { class size. }\end{array}$ & $\begin{array}{l}\text { Cooper and Robinson 2000b, } \\
\text { MacGregor 2000, Goodman et } \\
\text { al. 2005, O'Reilly et al. 2007, } \\
\text { Hejmadi 2007, Grauer et al. } \\
\text { 2008, Lin et al. 2010, Mulryan- } \\
\text { Kyne 2010, Nagel and Kotzé } \\
\text { 2010, Exeter et al. 2010b, } \\
\text { Stanger-Hall et al. 2010, Kelly } \\
\text { et al. 2010, Klegeris and } \\
\text { Hurren 2011, Nicholl and Lou } \\
\text { 2012, Schmitt-Harsh and } \\
\text { Harsh 2012, Wixon and Balser } \\
\text { 2012, Lian 2013, Miller et al. } \\
\text { 2013, Prosser and Trigwell } \\
\text { 2013, Wu 2013, Johanson et }\end{array}$ \\
\hline
\end{tabular}




\begin{tabular}{|c|c|c|}
\hline & & $\begin{array}{l}\text { al. 2013, Klegeris et al. 2013, } \\
\text { Calzada et al. 2014, Naude } \\
\text { and Derera 2014, Woollacott } \\
\text { et al. 2014, Swap and Walter } \\
2015\end{array}$ \\
\hline $\begin{array}{l}\text { 3.Classroom } \\
\text { management }\end{array}$ & $\begin{array}{l}\text { The design and } \\
\text { organisation of teaching } \\
\text { and learning activities } \\
\text { and the way they are } \\
\text { assembled play a key } \\
\text { role when implementing } \\
\text { large-group activities. }\end{array}$ & $\begin{array}{l}\text { Cooper and Robinson 2000a, } \\
\text { Renaud et al. 2007, Nelson et } \\
\text { al. 2009, Lin et al. 2010, } \\
\text { Stanger-Hall et al. 2010, } \\
\text { Johanson et al. 2013, Klegeris } \\
\text { et al. 2013, Calzada et al. } 2014\end{array}$ \\
\hline $\begin{array}{l}\text { 4.Students' } \\
\text { motivation and } \\
\text { engagement }\end{array}$ & $\begin{array}{l}\text { A large-group compared } \\
\text { to a small one, should } \\
\text { not necessarily show } \\
\text { differences in students' } \\
\text { learning outcomes, as } \\
\text { long as all students are } \\
\text { motivated and engaged } \\
\text { in the learning process. }\end{array}$ & $\begin{array}{l}\text { Goodman et al. 2005, Hejmadi } \\
\text { 2007, Renaud et al. 2007, } \\
\text { Exeter et al. 2010b, } \\
\text { Tomkinson and Hutt 2012, } \\
\text { Denker 2013, Cahill et al. 2014 }\end{array}$ \\
\hline $\begin{array}{l}5 . \text { Use of } \\
\text { information } \\
\text { and } \\
\text { communicatio } \\
\text { ns } \\
\text { technologies } \\
\text { (ICTs) }\end{array}$ & $\begin{array}{l}\text { The use of online } \\
\text { teaching resources was } \\
\text { considered as important } \\
\text { aids that help solving the } \\
\text { challenges of large-group } \\
\text { activities in terms of } \\
\text { student's participation } \\
\text { and interaction. }\end{array}$ & $\begin{array}{l}\text { Roberts et al. 2005, Bryant } \\
\text { 2005, Dollman } 2005 \text {, } \\
\text { Goodman et al. 2005, Azzawi } \\
\text { and Dawson 2007, O'Reilly et } \\
\text { al. 2007, Yang 2008, Doucet et } \\
\text { al. 2009, Kelly et al. 2010, } \\
\text { Halic et al. 2010, Elavsky et al. } \\
\text { 2011, Nicholl and Lou 2012, } \\
\text { Qiu et al. 2012, Saunders and } \\
\text { Gale 2012, Kim 2013, Bati et } \\
\text { al. 2014, Snowball 2014, } \\
\text { Calzada et al. 2014, Foley and }\end{array}$ \\
\hline
\end{tabular}




\begin{tabular}{|c|c|c|}
\hline & & $\begin{array}{l}\text { Masingila 2014, Qiu and } \\
\text { McDougall 2015, Rohr and } \\
\text { Costello 2015, Shaw et al. } \\
2015\end{array}$ \\
\hline $\begin{array}{l}\text { Contrary } \\
\text { positions }\end{array}$ & $\begin{array}{l}\text { Pose the loss of } \\
\text { interaction between } \\
\text { teacher and students } \\
\text { decreasing the } \\
\text { achievement of learning } \\
\text { results. }\end{array}$ & $\begin{array}{l}\text { Gibbs et al. 1996, Arias and } \\
\text { Walker 2004, Cuseo 2007, } \\
\text { Kokkelenberg et al. 2008, } \\
\text { Bedard and Kuhn 2008, } \\
\text { Cardozo et al. 2008, Persky } \\
\text { and Pollack 2010, Johnson } \\
\text { 2010, Kooloos et al. 2011, } \\
\text { Cheng 2011a, 2011b, } \\
\text { Truelove et al. 2013, } \\
\text { Westphalen 2013, Allais 2014, } \\
\text { Saiz 2014, Hornsby and } \\
\text { Osman 2014 }\end{array}$ \\
\hline
\end{tabular}

